\title{
Professionalism of Islamic spiritual guide
}

\section{Susana Aditiya Wangsanata*, Widodo Supriyono, Ali Murtadho \\ Universitas Islam Negeri (UIN) Walisongo, Semarang, Indonesia \\ Email: sswangsanata5@gmail.com}

\begin{abstract}
Purpose - The aim of this research was to recognize radically (deeply) the professionalism of Islamic spiritual guides.

Method - This research used descriptive qualitative with the determination of informants using the model of snowball. The data analysis in this study used Creswell's theory of analysis ranging from data reduction, display, and to conclutions.

Result - The results of this study indicate that a professional Islamic spiritual guide needs to meet three indicators in order to carry out counseling process optimally. The indicators of professionalism are relevant educational qualifications, expertise or qualified credibility, and finally the presence of payment commensurate with the quality of work. Meanwhile, the professionalism of Islamic spiritual guidance services is to pay attention to the time and material given to counselees so that they can display or provide Islamic spiritual guidance services professionally.

Implications - The implication of this research is to improve performance professionally by absorbing the experts or specialists in the field of Islamic spiritual guidance.

Originality - The originality of this study is that it is the first research model to apply the correlation research method with the LESKAP pattern.
\end{abstract}

Keywords: Professionalism, Islamic spiritual guide, hospital.

For citation: Wangsanata, S. A,. Supriyono, W,. \& Murtadho, A. (2020). Professionalism of Islamic spiritual guide. Journal of Advanced Guidance and Counseling. 1(2). 101-120. https://doi.org/10.21580/jagc.2020.1.2.5919.

*Corresponding author: Susana Aditiya Wangsanata (sswangsanata5@gmail.com), Jl. Prof. Dr. Hamka No.3 - 5, Tambakaji, Kec. Ngaliyan, Kota Semarang, Jawa Tengah 50185. 
Susana Aditiya Wangsanata, Widodo Supriyono, Ali Murtadho

JAGC | 102

\begin{abstract}
Abstrak
Tujuan - Penelitian ini bertujuan untuk mengetahui secara radikal (mendalam) profesionalisme pembimbing spiritual Islam.

Metode - Penelitian ini menggunakan deskriptif kualitatif dengan penentuan informan menggunakan model snowball. Analisis data dalam penelitian ini menggunakan teori analisis Creswell mulai dari reduksi data, penyajian, dan penarikan kesimpulan.

Hasil - Hasil penelitian ini menunjukkan bahwa seorang pembimbing spiritual Islam profesional perlu memenuhi tiga indikator agar dapat melaksanakan proses penyuluhan secara optimal. Indikator profesionalisme diantaranya, kualifikasi pendidikan yang relevan, keahlian atau kredibilitas yang mumpuni, dan terakhir adanya perhatian yang sepadan dengan kualitas pekerjaan. Sedangkan profesionalisme layanan bimbingan spiritual Islam adalah dengan memperhatikan waktu dan materi yang diberikan kepada konselor sehingga dapat menampilkan atau memberikan layanan bimbingan spiritual Islam secara profesional.

Implikasi-Implikasi dari penelitian ini adalah untuk memberikan saran dalam hal meningkatkan kinerja secara profesional dengan menyerap tenaga ahli atau spesialis di bidang pembinaan spiritual Islam.

Originalitas - Keaslian penelitian ini adalah model penelitian yang pertama kali menerapkan metode penelitian korelasi dengan pola LESKAP.
\end{abstract}

Kata kunci: Profesionalisme, pembimbing spiritual Islam, rumah sakit.

\title{
Introduction
}

The issue of professionalism 1 at work is an issue that needs to be studied in more depth because work professionalism is needed to achieve work objectives. According to Putra (2018), professionalism and work climate affect employee performance. The results of this study are in line with the results of Martak (2015) study which states that professionalism has a significant effect on job satisfaction. The other research conducted by Bolung et al (2018) states that professionalism and skills have an influence on job satisfaction. Then, Suwinardi (2017) shows that

\footnotetext{
${ }^{1}$ Law Number 43 of 1999 writes on the Principles of Civil Service, the words professional and professionalism with various editors are repeated up to ten times. This phenomenon shows that the people's aspirations for quality services are getting higher along with the higher level of public awareness and education
} 
professional competence is needed to carry out a profession. Professionalism is characterized by high integrity, methodical competence, and social competence.

Various research results above indicate that the importance of professionalism in work so that it has an impact on job satisfaction. This is the basis that professionalism at work needs to be carried out by competent personnel in the JAGC | 103 field of work. Based on the reality in Indonesia, many people work but do not match their academic fields or educational background. This has become commonplace in society even though there is no certainty of real data which indicates a gap or mismatch of academic competence with the field of work. Furthermore, this does not interfere with the work process carried out, so it can also show a form of professionalism in work.

The common reality above raises a speculation that work professionalism can be done when the field of work has been done properly. This is in line with the form of professionalism of Islamic spiritual guides at the Roemani Muhammadiyah Hospital Semarang in which the Islamic spiritual mentors at the Roemani Muhamamdiyah Hospital Semarang did not all have academic competence or educational background as counselors, religious counselors, or spiritual guides, but they can carry out the guidance process properly. This is of course a problem in the academic world which shows that there is a gap or mismatch between ideals and reality in the field.

Ideally, Islamic spiritual guides formally or academically receive education, training and competence from the authorized educational institutions. Islamic spiritual guides are specially trained to master the set of skills needed for the counselee's (patient) of spiritual guidance process (Hidayanti, 2015). However, as the researcher states above, many people do not work in accordance with educational competencies, including Islamic spiritual mentors in hospitals.

Academic and practical competence are the main assets to be able to carry out the guidance process professionally. Where Islamic spiritual guides are required to understand the content and essence of Islamic teachings, namely mastering the content of Al Qur'an and as-Sunnah (Hidayanti, 2014). Thus, academic and practical competence can be combined with the content of the holy verses of Al Qur'an and 
as-Sunnah. This combination is a distinctive feature and demonstrates the expertise of an Islamic spiritual guide in providing spiritual guidance practice to patients. These characteristics demonstrate professionalism in spiritual mentor of Islam that should be supported by the expertise, commitment and skills relevant to the basic principles of "well-educated (educated), well trained (trained), well paid (paid)" (Basit, 2006). Therefore, professionalism must be prioritized to fulfill these aspects, and it is necessary to refer to science and have syakilah.

Idealnya, pembimbing rohani Islam secara formal atau akademik mendapatkan pendidikan, pelatihan dan kompetensi yang oleh lembaga atau institusi pendidikan yang berwenang menyelenggarakannya. Pembimbing rohani Islam dididik secara khusus untuk menguasai seperangkat keahlian yang diperlukan untuk proses bimbingan rohaniah konseli (pasien) (Hidayanti, 2015). Akan tetapi sebagaimana peneliti sebutkan di atas bahwa, banyak masyarakat yang bekerja tidak sesuai dengan kompetnsi pendidikan, termasuk tenaga pembimbing rohani Islam di rumah sakit.

Syakilah is the mastery of various kinds of BKI matter knowledge by having qualifications and a code of ethics. Islamic spiritual guides must be skilled in implementing them in an effort to provide ta'lim, tausiyah, advice and finding solutions to the problem of maradh al-qulub (mental disorder) (Sambas, 2014). Meanwhile, according to international regulations in the international standards of the North American Nursing Diagnosis Association (NANDA), it says that there are 9 aspects of spiritual care for patients, including; (1) knowledge to practice worship to patients, (2) increasing activities in the practice of worship to patients (3) managing stability of patient emotional, (4) having good interaction skills (5) having hope, (6) spiritual well-being (7) prosperous, (8) a quality life, (9) dying care or guidance for death in order to achieve the death of husn al-khatimah (Riyadi, 2019).

Thus, syakilah as a theoretical reference and NANDA as a practice reference can be a unity to form the professionalism of Islamic spiritual guides to call patients to have good religious qualities. Allah SWT spoke as follows: 


$$
\text { آدع إلى سبيل ربك بآلحكمة وآلموعظة آلحسنة وجدلهم }
$$

Meaning: "Call upon (human) to the way your Lord with wisdom and good lessons and argue them in a good way. Indeed, it is your Lord who knows better about those who have strayed from His paths and He is the one who knows better those who are guided"(Surah an-Nahl (16): 125). (Ministry of Religion, 2006).

JAGC $\mid 105$

The verse above illustrates the importance of the call so that the patient's efforts in addition to seeking medicine but also the obligation to maintain worship during illness to be able to fulfil the 9 aspects of NANDA. The practice of worship is adjusted to the patient's abilities as long as the patient still has elements of awareness. Actually, the practice of practicing patient worship in the hospital has a law of origin that lies in the ability of the patient alone. However, because the patient also has certain causes ('illat Hukum) in the form of obstacles, the environment has an obligation (fardu kifayah) to participate and help carry out patient worship practices. The law is sinful when the patient does not fulfill his religious obligations because he is not helped and cared for by the surrounding environment. The law of fardu kifayah is not only an obligation that can be represented, but it also means that obligations must be assisted in the practice of its implementation (Riyadi, 2019).

In line with the importance of preaching in the hospital, what is meant by da'wah in this research is a process of providing spiritual assistance to patients and their families in order to be able to live by the rules and provisions and guidance of Allah Almighty so as to achieve a prosperous life in this world and the hereafter (Faqih, 2001). This can be achieved when there is a team of professional health nurses such as doctors, nurses and therapists and other professionals such as social workers and Islamic spiritual guides (Hidayanti, 2014). Phil Barker and Poppy mentioned that non-medical professionals are anything outside or not related to the medical field. Meanwhile, spiritual is related to or psychological (spiritual, mental) (Barker \& Poppy, 2005).

Therefore, realizing a professional Islamic spiritual guide is an important part of the realization and command of the obligation to preach in Al Qur'an. This command is as contained in the sentences ولتكن and كنتم which give a guide on 
amar takwin (formation order) of Da'i (the preachers) who are educated and trained in carrying out da'wah tasks. Therefore, in other terms it is called professional Da'i (Muhyiddin et al, 2014).

Professional Da'i need to have qualifications in the field of education academically and practically so that they can preach professionally, especially to mad'u with special needs such as patients in hospitals. Thus, it can be seen that the gap or problem in this study is the incompatibility of the academic field or educational background of the patient's spiritual mentor at Roemani Muhammadiyah Hospital Semarang with the field of work being carried out. As expressed by the researcher above, as a result of previous research, it shows that it is important that professionalism will have an impact on job satisfaction so that job service recipients can feel service satisfaction. Then, the researcher has a speculation (allegation) and a hypothesis that, first, the researcher's speculation is, the professionalism of Islamic spiritual guides needs to have academic and practical competence so as to lead to job satisfaction. Second, the researchers have a hypothesis that the work professionally can be done when the job is properly and well occupied.

\section{Research Method}

This research was a qualitative field research (Riyadi, 2019). This approach explores, observes and analyzes activity, the process of a group or individual specifically. In this approach, it was more focused and specific than the phenomenological approach in which it is the researcher who takes and determines the specific phenomenon used as a research problem. After that, it determines the groups or individuals, times, places, and specific processes which are the focus of research (Manzilati, 2017). In this case, this approach was focused on the Islamic spiritual mentors at the Roemani Muhammadiyah Hospital Semarang starting from the educational background, expertise, payment and professionalism of Islamic spiritual guidance services to patients. 


\section{Results and Discussion}

\section{Professionalism of Islamic Spiritual Guides}

Professionalism is a characteristic of a professional person. It is the behavior, skills, and qualities of a professional person. Meanwhile, the elements of professionalism are; 1) capacity or expertise that comes from science and technology, 2) individual or group morals or ethics, and 3) service to people or society (Sulistio, 2013). These elements may be obtained through special educational studies, such as education as a counselor, extension agent, and Islamic spiritual guide.

\section{The importance of education and training to achieve work professionalism standards}

Education and training in article No. 1 concerning Government Regulation No. 101 of 2000 states that education and training is a process of implementing learning and teaching in the context of increasing the capacity of civil servants or PNS. The purpose of education and training is to make Islamic Islamic spiritual advisors or employees have the ability (skills) so that it has an impact on the practice of the services provided (Rusdin, 2017).

Then, education and skill trainings are important factors that need to be considered as a means of realizing the work standards of Islamic spiritual guides. Education and training will increase knowledge and skills at work so that the productivity of the Islamic spiritual guide can be seen as good work success. Training is an attempt to increase the knowledge and skills of Islamic spiritual mentors. With an increase in skills, knowledge, insights, and attitudes on assignments through training programs that have been implemented within the organization, it can improve the performance of Islamic spiritual forces (Pakpahan, 2014).

In this case, the relevance of education to the standard of professionalism of Islamic spiritual guides at the Roemani Muhammadiyah Hospital Semarang has its own criteria. These standards can be seen in the following table: 
Susana Aditiya Wangsanata, Widodo Supriyono, Ali Murtadho

Table 1. Professionalism Standards For Islamic Spiritual Guides at Reomani Muhammadiyah Hospital Semarang

The Standards of Professionalism for 1) Moslems.

Islamic Spiritual Guides at Roemani

JAGC | 108

Muhammadiyah Hospital in Semarang

2) Graduates of the Islamic Religion are

3) Able to Serve in Society

Based on the table above, the relevance of education and the standards of professionalism of Islamic spiritual guides at Roemani Muhammadiyah Semarang Hospital include three elements. First, professional Islamic spiritual guides are Muslims. Second, they have qualifications as a scholar of Islam from all majors, and there is no specific department requirement from an educational background. Third, they are able to carry out khutbah jum'at (Friday sermons) in the community. In addition, these standards are also the requirements to be Islamic spiritual guides. However, in the theory, the professionalism of the spiritual mentor of Islam should be supported by the expertise, commitment and skills relevant to the basic principle of "well-educated (educated),well-trained (trained), and well-paid (paid)" (Basit, 2006).

As an Islamic hospital, Roemani Muhammadiyah Hospital Semarang provides the health services held jointly by several work units involving multi-disciplinary knowledge and with different professional backgrounds. In the fatwa of the Indonesian Ulema Council (MUI) No. 107 / DSN-MUI / X / 2016 Regarding Guidelines for Hospital Management Based on Syari'ah Principles, there are several provisions, such as general provisions, the provisions related to contracts and legal personnel, the provisions related to services, the provisions related to medicines, food, drinks, cosmetics, and utility items, and the provisions related to the placement, use and development of hospital funds (Fatwa DSN MUI, 2016).

In addition, in the regulations related to health services, the hospital must provide religious consultation to patients and their families. This is a basic need for patients as religious beings who need spiritual touch to support their recovery. The provision of this religious consultation should be provided by Islamic spiritual advisers who have education and are trained in guiding the spirituality of patients in hospitals. The Islamic Hospital, ideally, provides spiritual consultation services as 
a hallmark of healing for patients. In addition, the provisions related to this service are applied by non-medical professionals because this is related to the patient's morals in dealing with illness (Muhson, 2004).

The interpretation of the MUI fatwa above shows that the profession of Islamic spiritual guidance requires a special level of education and training in order to achieve work professionalism standards. This means that the standard of professionalism is marked by a special expertise to carry out its professional duties. As for this privilege, it can be obtained by studying specifically because the standard of professionalism cannot be inherited. Being an Islamic spiritual guide is a life calling and carried out according to passion. Islamic spiritual mentors work full time, and not part time (Muhson, 2004).

Islamic spiritual counselors as professional spiritual guides for patients are needed in hospitals. Abdul Basit said that, apart from relying on physical treatment, patients also rely on personal approaches. This approach is not only from the doctors and nurses, but also from Islamic spiritual mentors (Basit, 2006). Thus, the practice of spiritual guidance to patients is an integral part of meeting the patient's bio-psycho-socio-religious and religious needs. The importance of providing guidance to patients is the implementation of a decree from WHO which says that religion is an element of the meaning of complete health (Marisah, 2018).

The efforts to realize the implementation of Islamic spiritual guidance at the Roemani Muhammadiyah Hospital Semarang properly and correctly require basic elements including education and training for Islamic spiritual mentors. Ignoring the elements of education and training will have an impact on the quality of services and the provision of guidance for patients and their families (Marliyanti, 2013). Therefore, the quality of service in ensuring and providing spiritual nursing care requires a professional attitude that can be obtained by education and training. Education and training for Islamic spiritual mentors will manifest the professionalism of spiritual nursing.

The education and training of Islamic spiritual guides can be measured by their expertise in accordance with the needs of the tasks assigned to them. There is an important reason between the suitability of knowledge and expertise that will have 
an impact on service quality. When the expertise possessed is not in accordance with the duties that must be carried out or assigned, the ineffectiveness of the service will continue to occur. Ineffectiveness means ineffectiveness in the practice of implementing guidance to patients and their families. Islamic spiritual mentors with special levels of education and training will show professionalism at work. This can be indicated by their mastery over their profession, taking their duties seriously, and their ability to communicate with patients. In other words, the ability of Islamic spiritual mentors continues to develop so that the quality of service is better (Aisyah, 2014) because one of the roles of an Islamic spiritual guide is to provide spiritual care and try to restore the psychological health of the patient. This service shows that patients are strived to always adhere to religious beliefs, so it creates a good commitment in the next life.

Religious commitment is very necessary in preventive efforts so that patients do not experience pain anymore. Religious commitment can also improve a patient's ability to cope with psychological problems. In a study by CNN in 1996 and USA Weekend in 1996, it concludes that, "more than $70 \%$ of patients believe that belief in Almighty God, praying and reciting dhikr can help the healing process of disease, while more than $64 \%$ of patients stated that it should be a doctor who provides psycho-religious therapy, prayer, remembrance". Based on the survey results, it shows that basically patients need religious therapy, apart from drug therapy and medical treatment (Darwanti, 2007).

According to Abdul Basit, apart from food, clothing and shelter which are basic human needs, being healthy is also a basic need that cannot be denied. No matter how good food, clothing and shelter are, when people are sick, of course they cannot enjoy them. Therefore, a healthy condition is a condition expected by humans, In this case, healthy physically, mentally (mentally) and socially (Basit, 2006).

\section{Indicators of Professionalism of Spiritual Guides in Islamic Hospitals.}

The indicators of professionalism in this study used by the researchers were Abdul Basit's opinion that professionalism must be based on three basic principles; education, expertise, and payment. The reason for choosing this opinion based on 
the three indicators represent the problem studied in which the aspects of education, trustworthiness and payment are the problems at the Roemani Muhammadiyah Hospital Semarang.

\section{a. Educational Background}

The educational background of Islamic spiritual advisors at the Roemani Muhammadiyah Hospital in Semarang, on average, is an alumni from the shari'ah faculty, and there was only one spiritual mentor as an alumnus of the Da'wah faculty majoring in Islamic guidance and counseling. In addition, some graduated from high school and had changed positions several times while working at the Roemani Muhamadiyah Hospital in Semarang. As an indicator of the principle of professionalism, the educational background of the patient spiritual counselors at Roemani Hospital Muhammadiyah Semarang has not met the requirements of professionalism. Therefore, this first indicator (educational background) has not been fulfilled.

\section{b. Expertise}

Based on the results of interviews with the patient spiritual counselors at the Roemani Muhammadiyah Hospital Semarang, it can be understood that they never received training to guide the patient's spirituality, except for one personnel who had educational qualifications as counselors, religious counselors, and patient spiritual advisers. Therefore, the second indicator of the principle of professionalism has not been fulfilled.

\section{c. Payment}

The standard of professionalism for spiritual counselors at Roemani Muhammadiyah Hospital Semarang, with reference to the basic principles of professionalism theory, can be seen in the following table. 
Susana Aditiya Wangsanata, Widodo Supriyono, Ali Murtadho

Table 2. Standard of Professionalism of The Spiritual Mentor of Islam at Roemani Muhammadiyah Hospital Semarang

\begin{tabular}{|c|c|c|}
\hline Service & Profesionalism Indicators & Implementation \\
\hline \multirow{3}{*}{ Professionalism } & $\begin{array}{l}\text { 1) Education (well- } \\
\text { educated) }\end{array}$ & $\begin{array}{l}\text { There are no special } \\
\text { provisions for education }\end{array}$ \\
\hline & 2) training (well-trained) & $\begin{array}{l}\text { Never trained spiritual } \\
\text { counseling patients }\end{array}$ \\
\hline & 3) Paid (well-paid) & Already implemented \\
\hline
\end{tabular}

The above table shows that the standard of professionalism of the spiritual mentor of Islam at Roemani Muhammadiyah Hospital Semarang has a ratio of 2 to 1 in which the comparison is more likely to lead to the absence of a specificity standard for spiritual mentors from the perspective of education and training.

Roemani Muhammadiyah Hospital Semarang has two aspects of service to cure patients; medical and non-medical aspects. The medical services are provided by professional doctors and nurses who are certified health professionals. The importance of professional doctors and nurses, of course, has an impact on the results of medical actions performed on patients. The professionalism of these medical services must also be followed by the professionalism of non-medical services. Professional non-medical services can only be provided by professionals as well as doctors and nurses. Why is that? Because non-medical services greatly affect the patient's physical healing process. Therefore, both medical and nonmedical services must be held by the personnel who are truly professionals in their fields.

Based on the explanation above, the professionalism of Islamic spiritual guides needs to fulfill three main indicators; education, expertise and payment. When these three indicators can be met, the process of implementing spiritual guidance to patients will run well causing satisfaction to the patient. As for the purpose of the need for professionalism of Islamic spiritual guidance, patients get holistic health both physically and psychologically. 


\section{Professionalism of Islamic Spiritual Guidance Services for Patients}

Meanwhile, the professionalism of spiritual mentors at the Roemani Muhammadiyah Hospital in Semarang is closely related to the requirements to become spiritual mentors. These requirements start from the perspective of mastery of religious knowledge and educational background. The requirements that have been determined by the hospital are the basic reference starting from academic, health and skills tests. The minimum skill aspect of the prospective Islamic spiritual mentor must be able to carry out the Friday sermon properly and correctly.

The three aspects are special education, skills training, and payment. When these three aspects have been fulfilled, it will produce a professional staff. When the Islamic spiritual mentor is a professional person, it will provide professional service practice so that the patient will feel satisfied with the services provided. Thus, patient satisfaction will be of its own value to be able to help cure the disease that is being suffered so that patients get benefit in life even though they have to be side by side with the illness they are suffering from.

Furthermore, three indicators of education, trustworthiness, and payment are the basic assets to be able to provide professional guidance because education and expertise are the forms of intellectual property so that it has an impact on the payments received. When the payment received is not in accordance with educational qualifications and expertise, the professionalism attitude of the work is likely to be ignored because they feel that the payment received is inappropriate. Thus, when analysed with a wise mindset, a correlation between professionalism and customer (patient) satisfaction emerges. The correlation is a form of causality or cause and effect; the professionalism of Islamic spiritual guides will have an impact on the patient's good or the benefit of the patient's life. This of course refers to the real form of da'wah activities.

Da'wah is one of the missions of the Muhamadiyah organization, including preaching in hospital settings. One of the ways to do preaching in a hospital setting is the implementation of patient psychological guidance at the Roemani Muhammadiyah Hospital Semarang. Da'wah activities, especially in hospitals, are 
not an easy matter to do. Given that the mad'u faced are the people who have special needs, namely being physically ill and having an effect on them psychologically. Therefore, the professional aspect greatly determines the results of the da'wah carried out by the Islamic spiritual guidance officer.

Islamic spiritual advisors at Roemani Muhammadiyah Hospital Semarang, in carrying out a job or activity, are required to have a competency in their field. With the competency possessed, the Islamic spiritual guide will be able to easily complete their work. Then, competence can be defined as the skills a person has to be able to achieve job goals well. Competence is also a combination of knowledge, skills, values and attitudes that are reflected in the habit of thinking and acting. Competence is a set of responsible intelligent acts that must be possessed by Islamic spiritual advisors at Roemani Muhammadiyah Hospital Semarang as a condition to be considered capable of carrying out tasks in the field of patient spiritual guidance. This is because competence is a factor that determines professionalism at work so that it has an impact on job satisfaction.

Job satisfaction is a positive feeling about work, which results from an evaluation of its characteristics. The indicators of job satisfaction are as follows: First, the job itself is related to the characteristics of the job and complexity of the work being carried out is fun and satisfying and provides challenges to employees. Either income or salary is the amount of wages received deemed appropriate. Salary is a fixed reward that is paid in the form of money periodically or with a fixed period, for example once a month. Third, promotion opportunities are the process of changing from one job to another in a hierarchy of authority and responsibility that is higher than the authority and responsibility that has been previously given, in other words, being given the opportunity to advance in that field of work. Fourth, supervision is a relationship between each employee and his direct supervisor. Fifth, co-workers are the co-workers in organizations and their interactions which are collaborative at work.

Meanwhile, performance is the result of work that can be achieved by Islamic spiritual advisors at the Roemani Muhammadiyah Hospital Semarang, in accordance with their respective authorities and responsibilities in an effort to achieve the goals of the hospital. Thus, performance is important for Roemani 
Muhammadiyah Hospital Semarang. The efforts to improve the performance of Islamic spiritual mentors include paying attention to the work environment, namely the variety of patients they face ranging from social, educational and religious backgrounds. The work environment is everything that is around Islamic spiritual mentors who can influence him / her in carrying out assigned tasks so as to provide satisfaction for patients and their families.

Satisfaction is a form of feeling happy for the patient and his / her family which comes from the comparison between the pleasure of the patient's spiritual guidance services and medical action. Patient satisfaction is the level of patient feelings that arise as a result of the performance of health services obtained after the patient compares with what he expected. Therefore, it can be understood that satisfaction is the feeling that is obtained after service users get the experience they expect. Therefore, the quality of spiritual guidance services in guaranteeing and providing religious nursing care requires an attitude of professionalism.

In this case, job satisfaction is a manifestation of the implementation of spiritual guidance to patients in which the presence of spiritual guidance services for patients can be a complement to the existing service system. Ideally, this task is inherent in physicians, psychologists, psychiatrists, and existing medical professionals. However, in reality, this is difficult to materialize, due to the lack of knowledge and the limited time and energy available to doctors and medical personnel, both in the social and religious fields. Basically, the provision of spiritual or spiritual guidance services like this is also a part of the duties of the existing medical or nurse. However, in reality they are more focused on carrying out tasks in the medical field, so this task is neglected. Functionally, the area, under which spiritual guidance service officers work for patients, is different from the focus of the existing doctor or psychologist. The field of assignment, in the field of spiritual guidance services for patients, focuses on the spiritual and social dimensions of the patient. This is an area that is rarely explored by medical and non-medical tasks. Therefore, the presence of nurse officers or patient spiritual guides can complement the implementation of the service system for patients (Riyadi, 2019).

Based on the various statements above, it can be understood that the professionalism of Islamic spiritual guidance services is closely related to the 
requirements to become spiritual workers at the Roemani Muhammadiyah Hospital Semarang, scholars of religion, and understand the science of religion globally. These requirements do not have specific criteria such as the ability to understand individuals (patients) and have therapeutic communication skills and graduates from Islamic counselling. In addition, another requirement is to be able to become religious staff at the Roemani Muhammadiyah Hospital Semarang, which must be able to carry out Friday sermons and to fill recitations in the public.

\section{Meeting Point of Professional Islamic Spiritual Guide with LESKAP Model: Logical, Empirical, Systematic, Coherent, Axiological, and Pragmatic}

Based on the explanation above, the reduction, display and conclusion of the data, with a deep (radical) mindset, the researchers found another side or something else from this research as a form of novelty. As for measuring the novelty of this research, the researchers used the LESKAP analysis pattern, which then led to a statement that the need for "unity of science for professionalism Islamic spiritual guidance" which means that there is a need for "unity of science for Islamic spiritual guides" analysed by LESKAP. This means that the process of Islamic spiritual guidance is a logical form of da'wah, which is carried out on mad'u with special needs. Then, by borrowing the theory of causality, namely the cause and effect that the existence of a professional spiritual guidance process is due to the academic and practical abilities that the mentors at Roemani Muhammadiyah Hospital in Semarang must have empirically. Systematic, meaning that the implementation of Islamic spiritual guidance professionally, must have a clear work pattern in a sequence and coherent, starting from the patient's self-data collection, history of illness, to the diagnosis of non-medical healing. Coherence, the professionalism of Islamic spiritual guides, is related to the fardiyah da'wah pattern which focuses on mad'u with special needs. Therefore, it is necessary to have special academic and practical skills, such as specific communication and individual understanding. In axiological, the professionalism of Islamic spiritual guides was actually carried out by Islamic spiritual mentors at the Roemani Muhammadiyah Hospital Semarang. This is also a form of implementation of the purpose of da'wah to invite mad'u to the goodness of life. Pragmatic, meaning that the professionalism of Islamic spiritual guides, has useful, practical value in everyday 
life. Then, the pragmatic value is a consequence of varied academic and practical knowledge possessed by the patient's spiritual mentor. Thus, there is a meeting point that is in harmony between professionalism and the LESKPA analysis pattern which then provides an answer that it is indeed necessary to "unity of science for professionalism Islamic spiritual guidance".

\section{Conclusion}

The standard of professionalism of spiritual counsellors at the Roemani Muhammadiyah Hospital in Semarang is that they are Muslim, have a degree in religion (whatever the major is), and can perform Friday sermons. At the Roemani Muhammadiyah Hospital Semarang, there is no standard as a professional ideal in carrying out spiritual guidance to patients. This can be seen in, first, in terms of the educational background of all spiritual guides, and then the skills and expertise they have, whether they are in accordance with their passion or not. Second, some of the total spiritual guiding force are transfers from other work units. This certainly shows that as if a spiritual guide can be used by anyone to fill a lack of personnel. Third, there are some patients who did not carry out the SOP properly. This means that there are several SOPs that were not implemented.

The implementation of Islamic spiritual guidance at the Roemani Muhamamdiyah Hospital in Semarang has not led to professional services. There were patients who felt that the guidance provided is not optimal. Therefore, the education and training factors have an impact on the services provided which are still not maximal. The lack of maximum practice of guidance can be seen at the time of implementation, and then the material was emphasized on the problem of prayer. The professionalism of the spiritual mentors' da'wah at the Roemani Muhamamdiyah Hospital in Semarang needs to be improved. This can be seen in terms of the time of the visit and material provided. The time to visit the patient should be considered again because some patients felt uncomfortable when they had to rest but there was a visit from a spiritual advisor. In addition, the material provided did not only focus on the aspect of giving prayers even to the patients with minor illnesses. Therefore, the indicators of da'wah can be said that professionals must meet the $5 \mathrm{~W}+1 \mathrm{H}$ elements because the da'wah process is a 
Susana Aditiya Wangsanata, Widodo Supriyono, Ali Murtadho

communication process, namely the delivery of religious messages to patients. When one of these elements is not fulfilled, the da'wah process will not run properly and correctly.

\section{JAGC | 118 References}

Aisyah, N. (2014). Profesionalitas dakwah kontemporer. Jurnal Dakwah Tabligh, 15(2), 233-244.

Barker, P. \& Poppy, B. (2005). Spirituality and mental health breakthrough. Brigham Young University, Department of Counseling Psychology and Special Education, Provo, UT, US.

Basit, A., \& Wachid, A. (2006). Wacana dakwah kontemporer. STAIN Purwokerto Press.

Bolung, G. R., Tewal, B., \& Sepang, J. (2018). Pengaruh profesionalisme dan keterampilan terhadap kepuasaan kerja serta dampaknya terhadap kinerja pegawai Badan Perencanaan Pembangunan Daerah provinsi Sulawesi Utara. Jurnal EMBA: Jurnal Riset Ekonomi, Manajemen, Bisnis dan Akuntansi, 6(4). DOI: https://doi.org/10.35794/emba.v6i4.21298.

Darwanti, D., Handoyo, H., \& Kamaluddin, R. (2007). Bimbingan rohani dan pengaruhnya terhadap penurunan tingkat kecemasan pada ibu primigravida dengan persalinan kala I Di RSU Banyumas. Soedirman Journal of Nursing, 2(1).48-54.

http://www.jks.fikes.unsoed.ac.id/index.php/jks/article/view/98.

Fatwa of National Syari'ah Council - Indonesian Ulama Assembly, 2016.

Faqih, A. R. (2001). Bimbingan dan konseling dalam Islam. Yogyakarta: UII Press

Hidayanti, E. (2015). Dasar-dasar bimbingan rohani Islam. Semarang: CV Karya Abadi Jaya.

Hidayanti, E. (2014). Dakwah pada setting rumah sakit: (studi deskriptif terhadap sistem pelayanan bimbingan konseling islam bagi pasien rawat inap di rsi sultan agung semarang). Konseling Religi Jurnal Bimbingan Konseling Islam, 5(2), 223-244. doi: http://dx.doi.org/10.21043/kr.v5i2.1049.

Marlianti, M. (2017). Studi tentang profesionalisme aparatur dalam pelaksanaan good governance di Kec. Linggang Bigung, Kab. Kutai Barat. Jurnal Paradigma (JP), 2(1), 155-173. http://dx.doi.org/10.30872/jp.v2i1.350.

Manzilati, A. (2017). Metodologi penelitian kualitatif: Paradigma, Metode, dan Aplikasi. Universitas Brawijaya Press. 
Marisah. (2018). Urgensi bimbingan rohani islam bagi pasien rawat inap. Journal of Islamic Guidance and Counseling, 2(2). https://doi.org/10.30631/iigc.v2i2.21.

Martak, M. N. (2015). Analisis pengaruh profesionalisme dan komitmen organisasi terhadap prestasi kerja melalui kepuasan kerja pada auditor kantor akuntan publik di Surabaya. Jurnal Ekonomi dan Bisnis Airlangga (JEBA).Journal of Economics and Business Airlangga, 25(1). https://ejournal.unair.ac.id/JEBA/article/view/4354.

Ministry of Religion. 2006. Al-Aliyy (Al-Qur'an and its translation). Bandung: Diponegoro.

Muhson, A. (2004). Meningkatkan profesionalisme guru: Sebuah harapan. Jurnal Ekonomi dan Pendidikan, 1(2). https://doi.org/10.21831/jep.v1i2.665.

Pakpahan, E. S. (2014). Pengaruh pendidikan dan pelatihan terhadap kinerja pegawai (Studi pada Badan Kepegawaian Daerah Kota Malang). Jurnal Administrasi Publik, 2(1), 116-121.

Putra, K. (2018). Pengaruh profesionalisme dan iklim kerja terhadap kinerja karyawan pada PT. Bank Tabungan Negara kantor cabang Malang. Jurnal Aplikasi Manajemen dan Inovasi Bisnis (JAMIN)., 1(1), 61-74. http://dx.doi.org/10.47201/jamin.v1i1.6.

Suwinardi, S. (2017). Profesionalisme dalam bekerja. Orbith: Majalah IImiah Pengembangan Rekayasa dan Sosial, 13(2). http://dx.doi.org/10.32497/orbith.v13i2.965.

Riyadi, A . (2019). Standarisasi layanan bimbingan konseling Islam bagi pasien di rumah sakit Roemani Muhammadiyah Semarang (perspektif Dewan Syari'ah Nasional Majelis Ulama Indonesia. Dissertation PhD. Universitas Islam Negeri Walisongo Semarang.

Rusdin. (2017). Pendidikan dan pelatihan sebagai sarana peningkatan kompetensi guru di SMP Negeri 02 Linggang Bigung. Jurnal Administrative Reform. 5(4). http://dx.doi.org/10.30872/jar.v5i4.885.

Sambas, S. (2014). Konseling Islam: Profesi dan tantangannya perspektif Qur'anSunnah, dalam kajian dakwah multiperspektif. Bandung: Remaja Rosdakarya.

Muhyiddin, A., Muhtadi, A. S., Hamad, I., Mufid, A. S. I., Sambas, S., Sarbini, A., ... \& Safeí, A. A. (2014). Kajian dakwah multiperspektif teori, metodologi, problem dan aplikasi. Bandung: Remaja Rosdakarya. 
Susana Aditiya Wangsanata, Widodo Supriyono, Ali Murtadho

Sulistio. (2013). Dukungan sosial terhadap wacana sertifikat da'i ditinjau dari altruisme dan profesioanlisme dakwah (studi pada para mubaligh di Kota Semarang). Research Reports, Institute for Research and Community Service of IAIN Walisongo Semarang.

JAGC | 120 